\title{
ENTRE "ANTIGOS" E "SELVAGENS": NOTAS SOBRE OS USOS DA COMPARAÇÃOO \\ NO IHGB
}

Rodrigo Turin
Pós-doutorado DH-FFLCH/USP e Bolsista Fapesp

\section{Resumo}

A apresentação pretende mapear alguns dos usos das categorias "selvagem" e "antigos" pelos letrados do Instituto Histórico e Geográfico Brasileiro, entre as décadas de 1840 e 1870. A partir do estudo de tais categorias, de seu uso como instrumento comparativo, procura-se compreender os embates que foram travados no IHGB no que diz respeito à autoridade do passado e à estruturação de uma ordem do tempo. 
Qual o lugar dos antigos quando se trata de escrever a história da nação? Que espaço lhes atribuir quando a tarefa do historiador deve se concentrar em estabelecer os documentos da nacionalidade, determinar sua cronologia, os elementos de sua formação, o sentido de sua história? O que eles podem oferecer a um programa tão fortemente delineado, cuja esmagadora hegemonia não deixa espaço a outros objetos (e objetivos) historiográficos senão aqueles que podem incluir-se sob a rubrica "nação"? ${ }^{1}$ O que resta, enfim, da autoridade dos antigos quando todo esforço está dirigido a garantir a legitimidade dos modernos? ${ }^{2}$ Ao interrogar os usos dos antigos na Revista do Instituto Histórico e Geográfico Brasileiro, não há como fugir a essas questões. Um primeiro olhar sobre os artigos publicados na revista durante seus primeiros vinte anos de existência revela a completa ausência de investigações acerca da Antiguidade clássica. $\mathrm{Na}$ distribuição dos espaços ali realizada, fica patente a sua não inserção enquanto objeto histórico - pelo menos não diretamente. Tanto nos estatutos como nos programas que balizaram as tarefas do IHGB, tudo girava em torno da construção deliberada e urgente de uma história nacional ainda inexistente, não havendo, por conseguinte, justificativa para outros interesses intelectuais.

Contudo, se os antigos ali não aparecem como objetos exclusivos de investimento historiográfico, eles também não deixam de ser invocados nos textos produzidos pelos sócios do IHGB. A constatação dessa presença, concretizada de modo abundante na forma de epílogos, citações e comparações, indica, entre outras coisas, a familiaridade desses autores com a tradição clássica e, como ressaltou Roberto Acízelo de Souza, o importante papel que a eloquência continuava a desempenhar no Império. ${ }^{3}$ Convém lembrar, portanto, que se o objetivo era construir uma história moderna (ou filosófica) da nação, não foi esse o modelo historiográfico no qual eles próprios se educaram. A constatação dessa presença vem trazer, desse modo, alguns problemas para a compreensão do processo de formação de um conceito moderno de história no Brasil, em sua temporalidade e especificidade. Afinal, os deslocamentos semânticos implicados na formação de um regime moderno de historicidade levavam, em princípio, a uma perda da capacidade do passado em oferecer lições ao presen-

\footnotetext{
${ }^{1}$ Temístocles Cézar propõe a expressão "retórica da nacionalidade" para definir esse esforço discursivo do IHGB. Cf. CEZAR, Temístocles. L'écriture de l'histoire au Brésil au XIX siècle. Essai sur une rhétorique de la nacionalité. Le cas Varnhagen. Paris: ÉHESS, 2002.

${ }^{2}$ BLUMENBERG, Hans. The legitimacy of modern age. Cambridge: MIT Press, 1985.

${ }^{3}$ SOUZA, Roberto Acízelo de. O império da eloquência. Rio de Janeiro: EdUERJ/EdUFF, 1999.
} 
te. ${ }^{4}$ Deixando de ser fonte de autoridade, o passado deveria ser compreendido em sua própria historicidade. Como entender, então, essa presença dos antigos enquanto figuras de autoridade nos textos do IHGB? Como "mero" recurso retórico? Mas, justamente, se o fim último da retórica é a persuasão, esta só pode realizar-se num reconhecimento da autoridade dos argumentos utilizados. ${ }^{5}$ Seria tal continuidade índice do lugar fundamental que as concepções hierárquicas continuavam a desempenhar no Império do Brasil, levando ao reconhecimento e à valorização, diferentemente de sociedades fundadas em princípios igualitários como os Estados Unidos de Tocqueville, da assimetria implícita na noção mesma de autoridade ${ }^{6}$ De todo modo, longe de ser algo naturalizado, porque ainda a ser construída, a elaboração de uma escrita moderna da história nacional não deixaria de coexistir e confrontar-se, de diferentes formas e com sentidos diversos, com a autoridade da tradição clássica. Meu objetivo, neste artigo, é justamente indicar uma dessas modalidades de uso dos antigos no IHGB; uma das formas, e certamente não a única, através das quais a tradição clássica foi erigida em figura de autoridade. ${ }^{7}$

Como já afirmou Temístocles Cézar, não houve no Brasil uma querela entre antigos e modernos, pelo menos não no formato ocorrido em países como França e Inglaterra. ${ }^{8}$ Houve, contudo, o que podemos chamar de uma "querela sobre o selvagem”. Desde a fundação do IHGB, em 1838, ficara claro que a escrita

\footnotetext{
${ }^{4}$ KOSELLECK, Reinhart. Futuro passado. Contribuição à semântica dos tempos históricos. Rio de Janeiro: Contraponto/Editora PUC-Rio, 2006.

${ }^{5}$ Como destacam Perelman e Olbrechts-Tyteca, todo orador que quer persuadir um auditório particular tem de se adaptar a ele. Por isso a cultura própria de cada auditório transparece através dos discursos que lhe são destinados, de tal maneira que é, em larga medida, desses próprios discursos que nos julgamos autorizados a tirar alguma informação a respeito das civilizações passadas". PERELMAN, Chaïm; OLBRECHTS-TYTECA, Lucie. Tratado da argumentação. A nova retórica. São Paulo: Martins Fontes, 2005, p. 23.

${ }^{6}$ D'ALLONNES, Myriam Revault. Le pouvoir des commencements. Essai sur l'autorité. Paris: Seuil, 2006.

${ }^{7}$ FOUCAULT, Didier et PAYEN, Pascal (orgs). Les autorités. Dynamiques et mutations d'une figure de référence à l'Antiquité. Paris: Éditions Jérome Millon, 2007.

${ }^{8}$ CEZAR, Temístocles. Anciens, modernes, sauvages, et l'écriture de l'histoire au Brèsil au XIX siècle. Le cas de l'origine des Tupis. Anabases, 8, 2008. Sobre a querela, cf. FUMAROLI, Marc. Les abailles et lês araignées. In: La querelle des anciens et des modernes. Édition établie par LECOQ, Anne-Marie. Paris: Gallimard, Folio Classique, 2001; LEVINE, Joseph. The battle of the books. History and literature in the Augustan Age. Ithaca: Cornell University Press, 1991.
} 
de uma história nacional implicaria também a atribuição de um lugar aos indígenas que então ocupavam o território brasileiro. $\mathrm{O}$ modo como essa reflexão foi configurada diz respeito à própria formação de um discurso etnográfico no Brasil, delimitando suas características e restrições. Como pude analisar em minha tese, a produção dos textos etnográficos do IHGB direcionaram-se ao esclarecimento de dois problemas principais. ${ }^{9}$ Primeiro, uma busca pela especificidade histórica das populações indígenas. Interessava desvendar quais eram suas origens, seus parentescos, suas divisões, em que estado se encontravam quando da chegada dos portugueses. Todos esses pontos tinham por fim estabelecer um juízo definitivo sobre a questão fundamental: se esses grupos que aqui se encontravam tinham sempre permanecido num "estado de natureza" ou, ao contrário, eram formas decaídas de civilizações anteriores. Para além da superficialidade do espaço, procurava-se reconstruir a profundidade do tempo. Um segundo problema que norteou os trabalhos etnográficos, decorrente do primeiro, dizia respeito à possibilidade ou não de se "catequizar" a população que ainda habitava o território, e qual seria o melhor método a se adotar. ${ }^{10}$

A interrogação sobre sua origem e o debate sobre sua catequização traduziam as preocupações dos sócios do IHGB em atribuir aos indígenas tanto um passado quanto um futuro - ou, mais especificamente, um passado que lhes possibilitasse sua inclusão ou exclusão do futuro nacional. Essa pauta de debate, definida entre as décadas de 1840 e 1860, convergiu para um cenário no qual, grosso modo, estavam os partidários da catequização, ocupados com a defesa da ideia de decadência dos povos indígenas, e os que a negavam, argumentando a incapacidade desses povos em sair de seu estado de natureza. De um lado,

\footnotetext{
${ }^{9}$ TURIN, Rodrigo. Tempos cruzados: escrita etnográfica e tempo histórico no Brasil oitocentista. Rio de Janeiro: UFRJ, 2009.

${ }^{10}$ Logo na quarta sessão do Instituto Histórico e Geográfico Brasileiro, realizada em 4 de fevereiro de 1839, o secretário geral, Januário da Cunha Barboza, leu para os sócios presentes seis questões que deveriam orientar as discussões da casa. Dessas seis questões, todas devidamente aprovadas, quatro diziam respeito às populações indígenas e as duas outras versavam sobre o processo de colonização portuguesa. Os problemas levantados em relação aos primitivos habitantes do Brasil detinham-se nos seguintes pontos: as causas de sua "espantosa extinção"; o que se deveria concluir sobre sua história, ao momento da descoberta do Brasil; se essa população era formada somente por grupos nômades, "e no primeiro grau da associação", ou se era descendente de alguma "das grandes nações do resto da América", guardando traços dessas civilizações; qual seria o melhor método para se colonizar os índios (se conviria seguir o sistema dos Jesuítas); e, por fim, se a introdução dos africanos teria prejudicado a civilização dos índios do Brasil. BARBOSA, Januário da Cunha. RIHGB, tomo I, 1839, p. 61.
} 
buscava-se defender a catequese como um modo de inclusão das sociedades indígenas provando que seu estado atual era uma forma decaída de civilizações anteriores. O que tornava interessante essa qualidade de "decaídos" atribuída aos indígenas, além de ser mais adequada à tradição de uma antropologia bíblica de presença acentuada no IHGB, era a conclusão, daí retirada, da existência pretérita de elementos civilizacionais, posteriormente esquecidos. O que indicava, por sua vez, uma narrativa histórica - ainda desconhecida - àqueles povos. De outro lado, especialmente com Varnhagen, procurava-se provar a incapacidade do selvagem em sair de seu estado de natureza, deslegitimando, assim, qualquer esforço de inclusão desses povos ao corpo do Império. Para ambos, era a investigação da história indígena, assim como a definição de sua historicidade, o que possibilitaria uma chave de compreensão e uma legitimação à ação política.

A etnografia, portanto, vinha a ser concebida como um tipo específico de escrita histórica voltada a povos desprovidos dos marcos de historicidade reconhecidos pela cultura histórica oitocentista. ${ }^{11} \mathrm{E}$, tal como a história propriamente dita, ela também necessitava de fatos. Contudo, na falta de documentos históricos, os únicos métodos capazes de fornecer tais fatos eram a arqueologia e, principalmente, a gramaticalização da língua indígena. Com estas operações, tornava-se possível, primeiro, instituir e selecionar objetos familiares, para em seguida compará-los, deduzindo daí uma história que fugia à consciência dos selvagens. Já que estes não cultivavam uma memória (poder-se-ia dizer com Ricoeur, uma "memória declarativa"), caberia ao etnógrafo extrair da "fala" e dos costumes dos indígenas indícios que permitissem reconstruir seu passado com a maior verossimilhança possível. ${ }^{12} \mathrm{O}$ recurso à comparação mostrava-se assim uma ferramenta fundamental na construção do que podemos chamar de "fato etnográfico". Comparavam-se os tupis com os tapuias, os indígenas brasileiros com o de outras regiões da América e Oceania, e mesmo o "selvagem" brasileiro com o camponês europeu. Com essa (re)construção do fato etnográfico, a comparação permitia ainda a elaboração de um tempo, fazendo surgir a historicidade escondida sob a aparência de um eterno presente. A escrita da história indígena, enfim, só poderia assumir a forma de uma (certa) história comparatista.

\footnotetext{
${ }^{11}$ GUIMARÃES, Manoel Luiz Salgado. História e natureza em Von Martius: esquadrinhando o Brasil para construir a nação. In: Manguinhos- História, Ciências, Saúde, vol. II, jul-out, 2000. ${ }^{12}$ RICOEUR, Paul. La mémoire, l'histoite, l'oubli. Paris: Seuil, 2001.
} 
Em meio a todo esse exercício comparativo, os sócios do IHGB não deixavam de acionar igualmente os antigos. O modo como os acionavam, contudo, inscrevia-se no objetivo mais amplo de fazer valer as posições políticas e intelectuais que demarcavam o debate etnográfico imperial, cindido entre os promotores da catequese e aqueles que a negavam. A aproximação entre "antigos" e "selvagens", desse modo, vinha a ser regulada por aquilo que se esperava extrair da comparação simultaneamente enquanto efeito de conhecimento e artifício retórico de persuasão: seja para enobrecer os indígenas, seja para acusar sua irrecuperável inércia histórica. Entre antigos e selvagens, os letrados do IHGB aproximavam e distanciavam esses termos fazendo um vir a favor ou contra o outro, já que, movimento de possibilidades recíprocas, dependia da escolha desse terceiro termo - quase sempre ausente - o caminho a ser traçado. Para exemplificar essas diferentes estratégias, tomarei alguns trechos da disputa travada entre dois autores que ocupavam posições antitéticas no debate etnográfico oitocentista: Gonçalves de Magalhães e Francisco Adolfo de Varnhagen.

O que motivou Gonçalves de Magalhães a escrever seu texto "O indígena perante a história", publicado na Revista do IHGB em 1860, foi sua leitura da História geral do Brasil; obra que reunia, segundo ele, todas as acusações que andavam espalhadas contra os selvagens, "concedendo-lhes apenas insignificantes virtudes, como penhores de imparcialidade". ${ }^{13}$ De fato, para Varnhagen, o papel que o selvagem brasileiro poderia ocupar no modelo de civilização que então se implementava era bastante restrito, ou quase nenhum. No prefácio à primeira edição de sua História geral, de 1854, o historiador já havia se colocado em aberta oposição à atitude hegemônica no IHGB de promover a inclusão dos indígenas: "não falta - diz ele - quem seja de voto que se devem de todo reabilitar [os indígenas], por motivos cujas vantagens de moralidade, de justiça ou de conveniência social desconhecemos". ${ }^{14}$ Como historiador que sacrifica tudo às "convicções da consciência", ele não se deixaria levar por "figuradas

\footnotetext{
${ }^{13}$ MAGALHÃES, D. J. Gonçalves. Os indígenas do Brasil perante a história. RIHGB, tomo XXIII, 1860 , p. 7.

${ }^{14}$ VARNHAGEN, F. A. de. Historia geral do Brasil, isto é do descobrimento colonisação, legislação e desenvolvimento deste Estado, hoje imperio independente, escripta em presença de muitos documentos autenticos recolhidos nos archivos do Brazil, de Portugal, da Hespanha e da Hollanda. Madrid, 1854, p. XXI.
} 
ideias de brasileirismo". No segundo tomo de sua obra, que apareceu em 1857 , Varnhagen inseriu um "Discurso preliminar" para responder às críticas que havia recebido, ampliando sua agenda etnográfica com o objetivo de legitimar sua posição política anteriormente afirmada. O programa de pesquisas que ele desenha, em conformidade com as questões que guiavam as pesquisas no IHGB, visava estabelecer a origem dos indígenas habitantes do território, determinar seu caráter e, com base nessas conclusões, formular as melhores medidas políticas a serem tomadas. ${ }^{15}$ Se os objetivos gerais eram similares àqueles desenvolvidos no Instituto, as expectativas, contudo, se mostravam bem diferentes. De forma sucinta e objetiva, ele apresenta as respostas a cada uma das questões colocadas, concluindo peremptoriamente:

os Índios não eram donos do Brasil, nem lhes é aplicável como selvagens o nome de Brasileiros: não podiam civilizar-se sem a presença da força, da qual não se abusou tanto como se assoalha; e finalmente de modo algum podem ser eles tomados por nossos guias no presente e no passado em sentimentos de patriotismo ou em representação da nacionalidade. ${ }^{16}$

Essas palavras, como não poderia deixar de ser, renderam-lhe uma série de críticas, entre as quais o texto apresentado por Gonçalves de Magalhães ao IHGB. Este texto, portanto, qualifica-se como uma ação de defesa e de "reabilitação" do indígena contra as acusações proferidas na obra de Varnhagen. Este, segundo Magalhães, teria escrito sua história assumindo de forma parcial e acrítica apenas a visão dos vencedores, expressa nos documentos oficiais e nas crônicas dos colonizadores que havia utilizado como fontes. Diante disso, Magalhães inicia seu estudo invocando a ética historiográfica à qual Varnhagen teria ignorado ao compor sua história: a imparcialidade. Não "nos esqueçamos que os vencedores querem ter toda a razão do seu lado, mesmo quando levan-

\footnotetext{
${ }^{15}$ A lista de questões é a seguinte: "1. Eram os que percorriam o nosso território, á chegada dos christãos europeos, os seus legitimos donos? 2. Viviam, independentemente da falta do ferro e de conhecimento da verdadeira religião, em estado social invejável? 3. Esse estado melhoraria, sem o influxo externo que mandou a Providencia por meio do christianismo? 4. Havia meio de os reduzir a amansar, sem empregar a coacção pela fôrça? 5. Houve grandes excessos de abuso nos meios empregados para essas reducções? 6. Dos tres elementos de povoação, indio, branco e negro, que concorreram ao desenvolvimento de quasi todos os paizes da America, qual predomina hoje no nosso? 7. Quando se apresentem discordes ou em travada luta estes tres elementos no passado, qual delles devemos suppor representante historico da nacionalidade hoje?". VARNHAGEN, F. A. de. Historia geral do Brasil, tomo II. Madrid, 1854, p. XVII.

${ }^{16}$ VARNHAGEN, F. A. de. Historia geral do Brasil, tomo II, p. XXVIII.
} 
tam fogueiras; e o historiador é um juiz reto, e não o panegirista da vitória a todo custo". ${ }^{17}$

Por oposição a Varnhagen, Gonçalves de Magalhães procura então provar que o estado atual das populações indígenas, longe de ser um estado de natureza irrecuperável, é antes fruto de um processo de decadência: "Habituamo-nos tanto a considerar os indígenas como selvagens sem lei nem grei, a despeito do que em contrário sabemos continuamos a raciocinar como si eles assim fossem; talvez pelo estado de decadência a que se acham reduzidos os que por esses sertões se refugiaram". ${ }^{18} \mathrm{O}$ que se costumava considerar como uma "natureza" selvagem não passaria, portanto, de mera "aparência", fruto de uma decadência que caberia à investigação etnográfica desvendar. "A selvageria completa é uma ficção", afirma ainda Magalhães, "ou uma decadência e aberração temporária do estado normal do homem, que dela tende sempre a sair voluntária e instintivamente, como de um estado de enfermidade". ${ }^{19}$

Para provar esta tese central, que o filiava a outros autores como Joaquim Norberto e Gonçalves Dias, um dos expedientes a que Magalhães recorre no decorrer de seu texto é a comparação dos selvagens com os antigos. Mas, antes de tecer essas comparações, ele não deixa de lembrar a seus leitores, logo de início, o lugar que a Antiguidade ocupa em sua própria tradição, fixando, ao mesmo tempo, a função que assume em seu texto: "O elemento europeu que constitui uma parte da população do Brasil, e ao qual devemos o incremento da nossa civilização, tem por si a história gloriosa dos seus antepassados, desde que herdeiros dos remanescentes da civilização grega e romana que combateram, deixaram por este mesmo combate o estado selvagem em que vivam" ${ }^{20} \mathrm{O}$ autor referenda, assim, a posição de origem que cabe à Antiguidade greco-romana na história da civilização ocidental. Essa posição de origem, convém ressaltar, longe de indicar qualquer condição primitiva dos antigos, qualifica-se antes pelo caráter de fundação daquilo que se entende como uma tradição europeia, da qual o Brasil se vincula pela colonização portuguesa. Essa herança, como inclui Magalhães em sua assertiva, foi o produto indireto de um combate no qual esses mesmos antepassados que garantiram o "incremento da civilização" no Brasil desempenharam, na Antiguidade, o papel de selvagens. Esta invocação assume

\footnotetext{
${ }^{17}$ MAGALHÃES, D. J. Gonçalves. Os indígenas do Brasil perante a história, p. 4.

${ }^{18}$ MAGALHÃES, D. J. Gonçalves. Os indígenas do Brasil perante a história, p. 51. Grifos meus.

${ }^{19}$ MAGAlHÃES, D. J. Gonçalves. Os indígenas do Brasil perante a história, p. 37.

${ }^{20}$ MAGALHÃES, D. J. Gonçalves. Os indígenas do Brasil perante a história, p. 6. Grifos meus.
} 
um tom ainda mais provocativo se lembrarmos que Varnhagen, no primeiro tomo de sua História geral, havia afirmado serem os tupis os nossos "invasores normandos dos tempos bárbaros". Ora, enquanto o objetivo de Varnhagen, com esta associação, era ressaltar o caráter bárbaro dos indígenas, a invocação por parte de Magalhães das invasões bárbaras tem um objetivo oposto: lembrar a origem selvagem/bárbara de sua própria civilização. No mesmo movimento em que fixa um valor aos antigos, parâmetro para as posteriores comparações, Magalhães sugere já a validade de sua tese (da possibilidade da catequização) por meio desta substituição de papéis entre o mundo antigo e a história brasileira: a convertibilidade do selvagem brasileiro à civilização assegura-se pelo próprio exemplo dos portugueses que colonizaram o Brasil!

Centradas principalmente em referências greco-romanas, as comparações tecidas por Magalhães entre antigos e selvagens buscavam produzir sempre a semelhança, e nunca a diferença. Pois é nesta semelhança produzida pela invocação da autoridade dos antigos, assim como pelo seu reconhecimento por parte dos letrados do Império (lembrando que toda autoridade deve ser reconhecida), que o autor garantiria seu propósito de reabilitação do indígena perante as acusações de Varnhagen. ${ }^{21}$ Todas as comparações seguem uma linha comum, com a aproximação entre os dois termos fazendo transferir ao selvagem o valor positivo já reconhecido aos antigos. Esta operação é toda voltada para a resolução daqueles problemas que então configuravam o debate etnográfico no IHGB, quais sejam: a atribuição de um passado aos indígenas e a possibilidade de sua catequização.

No que diz respeito ao primeiro ponto, Magalhães invoca as ruínas indígenas encontradas em diferentes regiões da América, como Cuzco, Tenochticlan e Tezenco - esta última denominada por ele de "Atenas americana". No Brasil, tais ruínas jamais foram encontradas, apesar de toda expectativa e esforços realizados pelos sócios do IHGB. De todo modo, como únicos traços materiais de um passado indígena, não deixavam de ser invocadas na disputa etnográfica brasileira, tal como o fazia Magalhães em seu texto: "documentos incontestáveis de uma

\footnotetext{
${ }^{21}$ Essa relação entre autoridade e reconhecimento foi bem destacado por Pascal Payen: "Le fait de reconnaître ainsi une autorité conduit à poser le problème de la relation qu'entretient cette dernière avec le pouvoir et avec la persuasion. L'autorité se distingue du premier en ce qu'elle ne s'exerce ni par la coercition ni par la violence ; 'là où la force est employée, l'autorité proprement dite a échoué'. Elle se différencie également de la persuasion en ce que persuader implique que l'on renonce a priori à la hiérarchie dont la reconnaisance fonde le lien d'autorité”. PAYEN, Pscal. Les anciens en figure d'autorité. In: FOUCAULT, Didier et PAYEN, Pascal (orgs). Les autorités. Dynamiques et mutations d'une figure de référence à l'Antiquité, op. cit., p. 9.
} 
civilização de caráter antigo e original, que denuncia gerações sucessivas e séculos para ter chegado a este ponto de grandeza e esplendor, tão fácil nos é supô-la anterior, como contemporânea da mais antiga civilização da Índia e do Egito”. ${ }^{22}$ Essa primeira equivalência tecida por Magalhães entre selvagens e mundo antigo tem por fim ressaltar a antiguidade indígena e sua historicidade. A posse de um passado histórico, tão extenso e "grandioso" como o das civilizações mais antigas, garantiria às sociedades americanas um critério de identificação caro à cultura histórica oitocentista através de sua inserção paralela a uma tradição (re)conhecida. A existência daquelas ruínas indicaria um movimento temporal ("gerações sucessivas e séculos") marcado por conceitos como "grandeza" e "decadência", constituindo, portanto, uma narrativa histórica àqueles povos. Afinal, para essa cultura histórica, mais do que representar as sociedades do passado, como afirma Simmel, as ruínas vinham representar o passado das sociedades. ${ }^{23}$

Além do valor de um passado histórico, que garantiria aos indígenas uma inserção temporal, Magalhães lança mão de outra comparação com os antigos, agora para refutar a ideia professada por Varnhagen de que a vingança seria o único sentimento conhecido dos selvagens. Aqui, a outra qualidade em jogo no debate etnográfico do IHGB a que os antigos são chamados a esclarecer e a autorizar é a sociabilidade natural do indígena, condição e legitimação de sua inserção à nação brasileira.

Na visão histórica de Varnhagen, a guerra exerce uma função importante; ela é parte integrante do processo histórico da civilização. ${ }^{24}$ A guerra praticada pelos indígenas, no entanto, não assume o mesmo papel que possui na história ocidental. No caso dos selvagens, ela é antes um ingrediente que os impede de criar laços sociais estáveis e, assim, sair de um estado de barbárie. O maior motivo dessa diferença seria justamente o "instinto de vingança" presente na alma indígena. Sendo, por excelência, um ser vingativo, incapaz de desenvolver qualquer sentimento de abnegação, o selvagem não estaria apto a conceber valores mais nobres que o ligassem a um passado e o projetassem a um futuro comum:

E começada uma vez a rixa, era transmitida de filhos a netos; pois que nessas almas, em que tanto predominavam os instintos de vingança, nenhum sentimento de abnegação se

\footnotetext{
${ }^{22}$ MAGALHÃES, D. J. Gonçalves. Os indígenas do Brasil perante a história, p. 11. Grifos meus. ${ }^{23}$ SIMMEL, Georg. The ruin. In: WOLFF. K. (org.). Georg Simmel: 1858-1918. Columbus: Ohio State University Press, 1959, p. 259-66.

${ }^{24}$ WHELING, Arno. Estado, história, memória: Varnhagen e a construção da identidade nacional. Rio de Janeiro: Nova Fronteira,1999, cap. 5.
} 
podia abrigar em favor do interesse comum e da posteridade. Nos selvagens não existe o sublime desvelo ou bairrismo, que nem sequer eles como nômades tinham bairro seu, como um sentimento elevado que nos impele a sacrificar o bem estar e até a existência pelos compatriotas, ou pela glória da pátria. ${ }^{25}$

Logo, a única "memória" que os selvagens estariam aptos a cultivar seria uma memória de vingança, a qual os condenaria a um presente contínuo. Ao contrário do homem civilizado, que somente é capaz de matar e de morrer graças a um sentimento mais elevado, de patriotismo, os selvagens agiriam por puro instinto. Sem leis, sem Estado, sem religião, sem noção de propriedade, sem escrita, eles são, aos olhos de Varnhagen, pura falta. ${ }^{26}$

É em oposição a essa descrição etnográfica do autor da História geral do Brasil, que Magalhães recorre novamente a exemplos do mundo antigo, cuja autoridade tem a função de inverter o valor atribuído por Varnhagen ao sentimento de vingança dos indígenas:

Essa simpatia natural - diz Magalhães -, que liga os indivíduos de uma mesma tribo, é o instinto de associação, a base fundamental da civilização e o gérmen da justiça; e não há de que fazer censuras se esse sentimento é tão forte no coração do homem livre. A destruição de Troia não teve por motivo senão a vingança de uma injúria; por motivo quase semelhante expulsaram os Romanos os Tarquínios, e destruíram a realeza; e outras muitas guerras e devastações nem sequer se coonestam com iguais visos de justiça. ${ }^{27}$

O que se mostra a Varnhagen como um sentimento bárbaro, essencialmente desagregador, torna-se, pela comparação tecida por Magalhães, a base mesma da civilização. Afinal, um cerco tão longo como o de Troia só poderia mesmo ser motivado ou por uma vingança instintiva, ou por sentimentos heróicos! Ora, o que vemos em Homero como nobre, parece sugerir Magalhães, por que veríamos aqui como simples "selvageria"? O que é instintivo nos indígenas, portanto, não é esse estado de natureza que desenha Varnhagen com sua

\footnotetext{
${ }^{25}$ VARNHAGEN, F. A. de. História geral do Brasil, op. cit., p. 15-16.

${ }^{26}$ A descrição etnográfica de Varnhagen pode ser bem caracterizada pelas palavras de Furet: "Sans lois, sans arts, sans gouvernements, bref sans histoire. Car une échelle de valeurs implicite dignifie toujours le temps, créateur dynamique des lois et des nations, au détriment de l'espace, distributeur passif des societés humaines". FURET, François. De l'homme sauvage a l'homme historique: l'expérience américaine dans la culture française au XVIII siècle. L'atelier de l'histoire. Paris: Flammarion, 1982, p. 199. Vale destacar que também para Varnhagen, como para o caso francês analisado por Furet, o sonho americano só poderia sobreviver na literatura, e não na ciência ou na política. ${ }^{27}$ MAGALHÃES, D. J. Gonçalves. Os indígenas do Brasil perante a história, p. 14.
} 
descrição etnográfica, e sim uma sociabilidade exemplar espelhada no mundo antigo. Inclusive, uma vez realizada essa aproximação entre os indígenas e os heróis homéricos, aqueles também se vêem justificados como objetos de uma epopeia, encaminhando a legitimação do próprio projeto literário encabeçado por Magalhães: "Por isso é que os feitos dos indígenas oferecem argumento simpático à nossa poesia nacional. E como bem notou o sr. Odorico Mendes: os selvagens, rudes e de costumes quase homéricos, podem prestar belos quadros á epopeia. O parecer de tão abalizado crítico, que nos deu Virgílio em português, e luta para interpretar Homero, é de tanto peso que decide só por si qualquer dúvida. Feliz me julgo de pensar como ele, que sabe o que é uma epopeia". ${ }^{28} \mathrm{~A}$ autoridade homérica, mediada, aqui, pela autoridade de seu tradutor moderno, vem garantir por si mesma a resolução da disputa sobre o selvagem, promovendo essa curiosa apropriação romântica de um modelo clássico. ${ }^{29}$

Essa comparação com Homero, tecida por Magalhães, não se restringia apenas ao objeto da epopeia, mas se estendia igualmente à sua escrita. A gramaticalização da língua indígena, como já mencionei, inseria-se como a principal operação na construção do "fato etnográfico". Reduzida em dicionários e gramáticas, a língua indígena tornava-se objeto de apreciação estética, cujo valor encontrava-se no próprio modelo de sua redução: a gramática latina. Tal redução permitia, assim, conformar a língua dos selvagens à mesma estrutura gramatical a partir da qual os próprios antigos se faziam presentes a esses letrados. Uma vez gramaticalizada, a oralidade selvagem ganhava a semelhança da linguagem homérica. Como diz Magalhães: "Pelo som e significação de muitos dos seus vocábulos e formação de palavras compostas, tem ela alguma analogia com a língua de Homero", ou ainda:

A sua língua é tão suave, elegante e copiosa, que segundo a opinião dos que a cultivaram e gramaticaram, não lhe levam vantagem a Grega e a Latina. Lingua (diz Montoya) tan copiosa y elegante, que con rason puede competir com las de fama. "E Simão de Vasconcelos exclama: Em que escolas aprenderam, no meio dos sertões tão acertadas regras de gramática, que não falta um ponto de perfeição da praxe de nomes, verbos,

\footnotetext{
${ }^{28}$ MAGALHÃES, D. J. Gonçalves. Os indígenas do Brasil perante a história, p. 63.

${ }^{29}$ Apropriação que, como se sabe, redundaria em certo fracasso, acabando o selvagem por ser representado de forma mais eficaz, por José de Alencar, no romance, essa forma essencialmente moderna.
} 
conjugações ativas e passivas? Não dão vantagem nisso as mais polidas artes dos Gregos e Latinos". ${ }^{30}$

O nível de perfeição gramatical da língua tupi, cuja "observação" estava ligada diretamente ao seu processo de gramaticalização a partir do modelo latino, era transposto para a argumentação não como um juízo de valor, mas como um juízo de fato. A analogia tecida por Magalhães entre a língua dos selvagens e aquela de Homero sugeriria, assim, um alto padrão cultural alcançado pelos povos autóctones do Brasil - senão em seu presente, ao menos em seu passado.

Nesta via de mão única, o único efeito visado pela comparação de Magalhães é a reabilitação do indígena por meio do exemplo dos antigos - estes, por sua vez, jamais são movidos dessa posição fixa de autoridade exemplar. Ao tecer uma série de aproximações entre os selvagens e os antigos, Magalhães lançava mão do prestígio reconhecido aos gregos e romanos erigindo-os como figuras de autoridade capazes de decidir a contenda sobre o indígena brasileiro. Nesse sentido, mais que tornar os antigos selvagens, o que sua operação visava como efeito era a nobilitação dos indígenas. ${ }^{31}$ Não um selvagem com vestes gregas, mas um grego despido em terras americanas! Já no caso de Varnhagen, o objetivo era o oposto. Não surpreende, assim, que o uso que o historiador faz da comparação siga um caminho inverso ao de Magalhães, gerando antes, como ressaltou Temístocles Cézar, uma primitivização dos indígenas e, por consequência, dos antigos. É o caso, por exemplo, da comparação feita por ele acerca do uso do botoque nos indígenas brasileiros e seu uso similar no Egito antigo, tal como representado em sua iconografia. Mais do que destacar a simples semelhança, a comparação de Varnhagen tem a ambição de trazer uma nova perspectiva sobre aquelas imagens há tempos conhecidas: "Nós vamos mesmo mais longe. Acreditamos poder explicar, por um uso primitivo de botoques nos lábios, estes pequenos apêndices que observamos nos deuses e reis do Egito, assim como nas múmias dos homens". ${ }^{32}$ Desse modo, não apenas os antigos

\footnotetext{
${ }^{30}$ MAGALHÃES, D. J. Gonçalves. Os indígenas do Brasil perante a história, p. 45.

${ }^{31}$ Sobre o uso do paralelo entre antigos, modernos e selvagens, cf. HARTOG, François. Anciens, modernes, sauvages. Paris: Galaade, 2005.

${ }^{32}$ VARNHAGEN, F. A. de. L'origine touranienne des américains tupis-caribes et des anciens egyptiens. Indiquée principalement par la philologie comparée: traces d'une ancienne migration em Amérique, invasion du Brésil par les tupis etc. Vienne: Librairie I. et R. de Faesy \& Frick, 1876. "Nous allons même plus loin. Nous croyons pouvoir expliquer, par un usage primitif de botoques aux mentons, ces appendicules que l'on y voit, chez les dieux et les rois d'Egypte, et
} 
vinham esclarecer os selvagens, mas também estes, num movimento inverso, poderiam produzir novas perspectivas sobre os antigos - ambos entendidos, então, como primitivos. Não era com o objetivo de lançar novas luzes sobre os antigos, no entanto, que Varnhagen tecia suas aproximações. O que suas filiações e comparações com o mundo antigo ambicionavam trazer ao leitor era, antes, a legitimação histórico-etnográfica das posições políticas e intelectuais que o qualificavam dentro da querela sobre o selvagem ocorrida no IHGB. ${ }^{33}$

Nesse sentido, convém ressaltar, ainda que brevemente, uma certa ambivalência no modo como Varnhagen produz essa primitivização dos antigos. Afinal, ele não toma os antigos como um bloco único e homogêneo. A aproximação entre tupis e mundo antigo limita-se basicamente ao cários, dos quais os indígenas brasileiros teriam descendido. Como afirma na segunda edição de sua História geral: "E hoje temos quase a convicção de que houve efetivamente para o Brasil uma grande emigração dos próprios Cários da Ásia Menor, efetuada talvez depois da queda de Troia". ${ }^{34}$ Varnhagen lança, aqui, uma hipótese por ele aventada em estudo anterior, quando colocava três períodos possíveis dessa migração dos cários para a América, sendo o terceiro, justamente, após a guerra de Troia. Cito trecho deste estudo:

Dois costumes que se conservaram nos Tupis poderiam contribuir na suposição de que a emigração ocorreu à essa época: são eles o de sacrificar os prisioneiros e o de tirar vingança de seus inimigos, mesmo após a morte, sobre seus cadáveres. Ora, nós encontramos estes dois costumes à época da Guerra de Troia; e Homero, do qual se acusa pouca generosidade por lhes fazer menção, não os teria inventado. ${ }^{35}$

Os tupis seriam, enfim, descendentes da guerra que funda a "ocidentaliade". A partilha original se encontraria, portanto, nesse passado que não deixa de

aussi dans les momies des hommes", p. 71.

${ }^{33}$ Sobre as operações etnográficas de Varnhagen e suas aproximações e distanciamentos de antigos, selvagens e modernos, remeto ao artigo de CÉZAR, Temístocles. Anciens, modernes, sauvages, et l'écriture de l'histoire au Brèsil au XIX siècle. Le cas de l'origine des tupis. Concordo com o autor quando afirma que os indígenas se tornam, para Varnhagen, "primitivos, testemunhas das origens da humanidade", p. 65.

${ }^{34}$ VARNHAGEN, F. A. de. L'origine touranienne des américains tupis-caribes et des anciens egyptiens, p. 57.

${ }^{35}$ VARNHAGEN, F. A. de. L'origine touranienne des américains tupis-caribes et des anciens egyptiens, p. 93. "Deux usages qui se sont conservés chez les Tupis pourraient contribuer à faire supposer que l'émigration a été entreprise à cette époque: ce sont ceux de sacrifier les prisonniers et de tirer vengeance de leurs ennemies, même après la mort, sur leurs cadavres. Or, nous 
ser reconhecido por Varnhagen como "clássico", onde a "memória ocidental" tem seu ponto zero. A partir dali, os dois caminhos, o da barbárie e o da civilização, foram trilhados, um no espaço, outro no tempo. O longo caminho da civilização, como o estabelece Varnhagen, era único, e foi trilhado pelos fenícios, pelos gregos e pelos romanos, que implantaram a civilização na Europa e "com a língua levaram à Lusitânia, e que mais tarde, auxiliada na indústria pela ilustração arábica, e, nos costumes pelas branduras do cristianismo, foi trazida a este abençoado país (...)" ${ }^{36}$ E então, por capricho da Providência, esses dois caminhos - o da barbárie e o da civilização - voltariam a se encontrar nos trópicos com a colonização portuguesa. Após os tupis, esses descendentes dos cários, terem invadido "com inauditas crueldades" as terras americanas, teriam que enfrentar agora a vingança da história: "A seu turno devia chegar-lhes o dia da expiação. Veio trazê-lo o descobrimento e colonização, efetuados pela Europa Christã" ${ }^{37}$ Aí termina a etnografia. Começa, então, a história.

O que me interessa destacar de tudo isso, enfim, é como a querela sobre o selvagem, tal como configurado pelo debate etnográfico oitocentista, desembocava indiretamente numa querela acerca da autoridade do passado e, mais especificamente, dos antigos. Num trabalho constante de aproximação e distanciamento, de conjunção e distensão, o uso das categorias "selvagem" e "antigos" parecia gerar efeitos no modo como passado, presente e futuro eram relacionados. Ora o passado, na figura dos antigos, vinha esclarecer e legitimar os selvagens, ora estes lançavam uma nova inteligibilidade, ainda que indireta e limitada, sobre os antigos. Operação de efeito recíproco, seu uso se inscrevia num processo mais amplo de reestruturação da ordem temporal. Uma análise

trouvons ces deux usages á l'époque de la guerre de Troie; et Homère, que l'on a accusé de peu de generosité pour en avoir fait mention, ne les aura pas inventés".

${ }^{36}$ VARNHAGEN, F. A. de. História geral do Brasil. Antes de sua separação e Independência de Portugal. $3^{\text {a }}$ edição. São Paulo: Melhoramentos, s/d, p. 54.

${ }^{37}$ Idem, Ibidem, p. 59. Essa visão de Varnhagen do processo histórico liga-se à sua concepção de um direito de conquista. Em seu Memorial orgânico ele deixa claro o direito básico que legitima a "história" brasileira como continuidade do passado colonial: "O Brasil pertence-nos pela mesma razão que a Inglaterra ficou pertencendo aos normandos quando a conquistaram... O primeiro direito de todas as nações conhecidas foi o da conquista". Memorial orgânico que à consideração das assembleias geral e provinciais do Império, apresenta um brasileiro. Dada a luz por um amante do Brasil, 1849, p. 127. 
do uso dessas categorias pode, assim, servir como uma chave de entrada para a compreensão das especificidades que caracterizaram a formação de um conceito moderno de história no Brasil oitocentista. Afinal, como bem observou Myrian Revault d'Allonnes em seu recente ensaio sobre a noção de autoridade: “Ainda que os modernos tenham se empenhado em se livrar do julgo da tradição, a proclamação de um novo começo histórico e político não cessou de acompanhar-se de uma referência ao antigo". ${ }^{38}$ Continuidade que não deixa de ser um índice dos próprios limites do projeto moderno de sua "autoinstituição".

\footnotetext{
${ }^{38}$ D'ALLONNES, Myriam Revault. Le pouvoir des commencements. Essai sur l'autorité, p. 139. "Bien que les modernes se soient attachés à secouer le joug de l'autorité et à récuser tout mode de légitimation lié á la tradition, la proclamation d'un nouveau commencement historique et politique n'a cessé de s'accompagner d'une référence à l'antique”.
} 